\title{
The importance of human dimensions research in managing harmful algal blooms
}

\author{
Marybeth Bauer ${ }^{1 *}$, Porter Hoagland ${ }^{2}$, Thomas M Leschine ${ }^{3}$, Benjamin G Blount ${ }^{4}$, Caroline M Pomeroy ${ }^{5}$, \\ Linda L Lampl ${ }^{6}$, Clifford W Scherer ${ }^{7}$, Dan L Ayres ${ }^{8}$, Patricia A Tester ${ }^{9}$, Mario R Sengco ${ }^{10}$, Kevin G Sellner ${ }^{11}$, \\ and Joe Schumacker ${ }^{12}$
}

Harmful algal blooms (HABs) are natural freshwater and marine hazards that impose substantial adverse impacts on the human use of coastal and marine resources. The socioeconomic and health impacts of HABs can be considerable, thereby making a case for "human dimensions" research to support HAB response. Human dimensions research is multidisciplinary, integrating social science, humanities, and other fields with natural science to enhance resource management by addressing human causes, consequences, and responses to coastal environmental problems. Case studies reported here illustrate the importance of human dimensions research. Incorporating such research into the scientific agenda - as well as into management decisions of public agencies concerned with natural resource management, environmental protection, and public health and welfare - requires the development of both strategic guidance and institutional capacity. The recent development of a multi-agency research strategy for HAB response and a strategic plan for human dimensions research represent two important steps in this direction.

Front Ecol Environ 2010; 8(2): 75-83, doi:10.1890/070181 (published online 10 Feb 2009)

$\mathrm{S}_{\mathrm{c}}^{\mathrm{c}}$ cience and policy leaders in the US and internationally have called for improved understanding of the human dimensions of coastal ecosystems and their management (US Commission on Ocean Policy 2004). Recognition of this need reflects an understanding of ecosystems as coupled human-environmental systems (also called socioecological systems; Adger et al. 2005). Programs such as the International Human Dimensions Program (www.ihdp.uni-bonn.de/) and the Long Term Ecological Research Network's initiative, Integrative Science for Society and the Environment (Collins et al. 2007), as well as the human dimensions research pro-

\section{In a nutshell:}

- Human dimensions should be a focus of research on harmful algal blooms (HABs)

- Human dimensions research is multidisciplinary, aiming at understanding human-environment interactions to broaden and enhance support for resource management

- A recent multi-agency strategy for human dimensions research is both innovative and valuable in the context of US and international HAB science and management

- Institutional change is required to further integrate human dimensions research into the scientific basis for, and practice of, coastal management

\footnotetext{
${ }^{1}$ National Oceanic and Atmospheric Administration (NOAA), National Ocean Service (NOS), National Centers for Coastal Ocean Science (NCCOS), Silver Spring, contracted by IM Systems Group, Rockville, MD*(marybeth.bauer@noaa.gov); (continued on p83)
}

grams of the US Forest Service and other federal agencies, provide innovative institutional models for integrating human dimensions research into coastal management. Research integrating human and environmental understanding to inform resource management is also available (Reiter et al. 2006). Such approaches are vital, but unfortunately atypical in coastal science and management.

A recent example highlights the lack of human dimensions research in the US. An external review panel found that "the capacity of the National Oceanic and Atmospheric Administration (NOAA) to meet its mandates and mission is diminished by the under-representation and under-utilization of social science" (NOAA/SSRP 2003). Developing adequate capacity is challenged by "a lack of formal understanding of what social science is and what its contributions can be, leading to an organizational culture that is not conducive to social science research" (NOAA/SSRP 2003). This situation is exacerbated by limited funding for social science research; NOAA's fiscal year 2005 budget of $\$ 3.4$ billion included only $\$ 24.4$ million $(0.7 \%)$ for social science research (Weiher 2006).

Here, we make the case for development of the institutional capacity needed to identify and implement human dimensions research priorities in governmental, academic, and non-governmental organizations. We illustrate such priorities through a discussion of novel examples related to harmful algal blooms (HABs). 


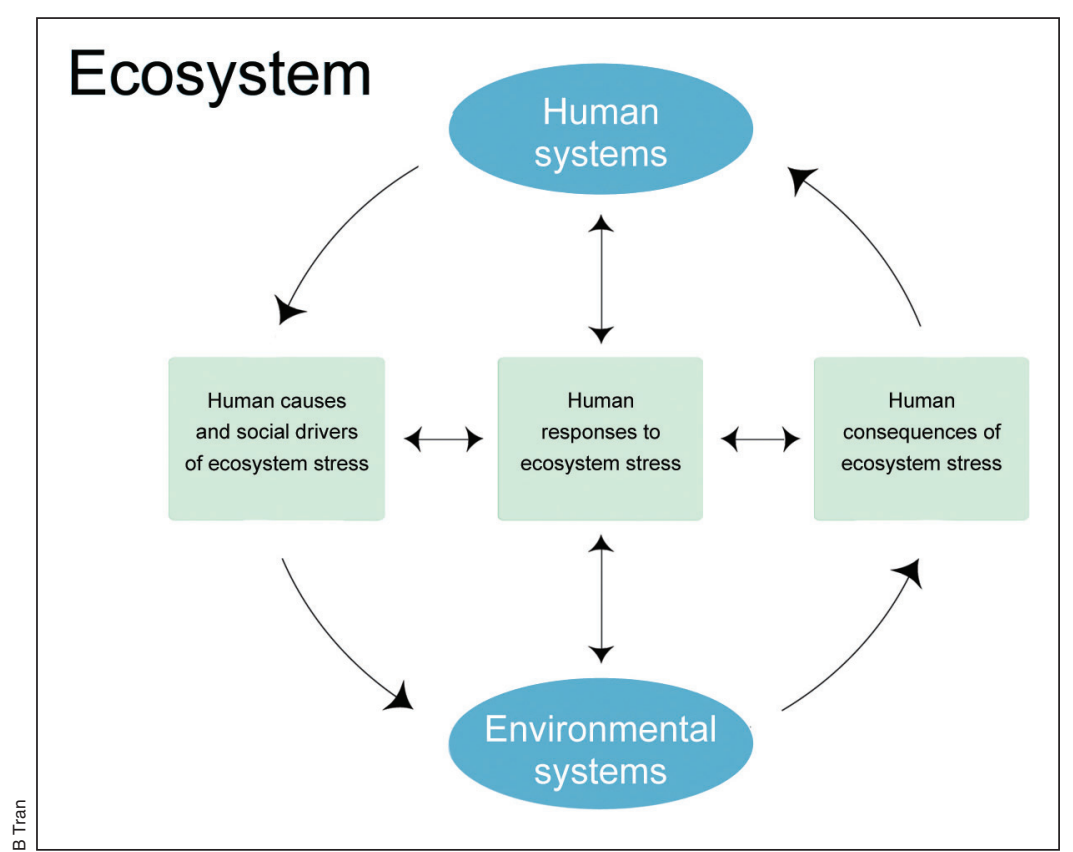

Figure 1. Diagram illustrating human dimensions of ecosystems (NOAA/ NCCOS 2007; adapted from NRC 1992).

\section{Human dimensions of ecosystems}

Because the neglect of human dimensions stems in part from a lack of social science literacy, it is important to review the human dimensions of ecosystems. Human dimensions can be described in terms of three points of interaction between human and environmental systems: human causes, consequences, and responses to environmental change (NRC 1992; Figure 1). Environmental change is caused by both human modifications (such as pollution and resource exploitation) and environmental forcing (such as climate variability and natural hazards). Such changes can influence the quantity, quality, and sustainability of ecosystem services, such as nutrient cycling, soil formation, water purification, flood control, and benefits that rely upon such services, including food production, recreation, and spiritual values (MA 2005). Changes in ecosystem services can have desirable or undesirable consequences for society, including aspects such as the degree of security from natural disasters, public health, social relations, economic productivity, and the freedom to pursue personal and cultural interests (Butler and Oluoch-Kosura 2006). Humans respond to undesirable consequences through mitigation and adaptation strategies, including resource management actions, to protect, restore, and sustain human values. Responses can have intended or unintended consequences for the environment and society, and, in some cases, they may contribute perversely to undesirable changes in ecosystem services.

Importantly, causes, consequences, and responses are intricately linked, because responses may modify causes to prevent or limit undesirable consequences, either anticipated or experienced (NRC 1992). Considerable uncertainty may surround the links between causes, conse- quences, and responses. We argue here that, in order to increase the likelihood of successfully mitigating consequences, either through the elimination of causes or the reduction of vulnerability to consequences, human dimensions research on these three points of interaction is essential.

Diverse disciplines in the social and behavioral sciences, humanities, communication sciences, and interdisciplinary fields contribute to a human dimensions research specialization focusing on human causes, consequences, and responses to environmental change (Figure 2). Human dimensions research supports coastal decision making in several ways (Endter-Wada et al. 1998). By explaining and predicting human causes, consequences, and responses to changes in ecosystem services, it broadens scientific understanding of coastal ecosystems. For example, whereas South Florida Everglades restoration has traditionally focused on water quality and delivery, Harwell et al. (1999) suggest an ecosystem approach, recognizing human-environment interactions. They emphasize the importance of establishing ecological sustainability goals that reflect societal values, examining societal factors such as land use that influence ecological sustainability, evaluating the role of governance and other institutions, and analyzing the societal consequences of alternative management scenarios. Whereas ecology focuses on changes to the structure and function of environmental systems, human dimensions research provides a view of how human behavior influences - and is influenced by - such changes, and how social systems can mitigate the consequences of HABs and adapt.

Insight into human psychology and behavior informs the coastal decision-making process that increasingly aims to combine ecosystem understanding with meaningful stakeholder participation (Endter-Wada et al. 1998) in establishing management objectives and evaluating tradeoffs. Participatory decision making not only honors the democratic right of citizens to participate in public policy, but can also help foster broader acceptance of management goals, suggesting improved management effectiveness (NRC 2008).

\section{Human dimensions of harmful algal blooms}

A multi-agency research strategy, Harmful algal research and response: a human dimensions strategy (HAB HD Strategy; Bauer 2006), provides guidance to enhance $\mathrm{HAB}$ response by expanding the human dimensions focus of HAB science and management. The strategy describes human dimensions research critical for implementing the "Public Health and Socioeconomic Impacts" section of the national HAB plan, Harmful Algal Research and Response: a National Environmental Science Strategy (HARRNESS 2005). Expanding HARRNESS, the HAB 
HD Strategy describes human dimensions research priorities and example projects to accomplish goals of the HAB scientific and management community related to: (1) socioeconomic impacts; (2) public health impacts; (3) recreational and drinking water impacts; (4) risk communication; (5) institutional coordination; and (6) education and outreach.

The HAB HD Strategy has proven to be both innovative and valuable in the context of US and international HAB science and management. For example, US HAB scientists and managers used the strategy to inform development of a congressionally mandated plan that proposes a new national research program to reduce impacts of HABs (Harmful Algal Bloom and Hypoxia Amendments Act 2004; Jewett et al. 2008; Dortch et al. 2008; Figure 3). Following dissemination of the HAB HD Strategy at the 12th International Conference on Harmful Algae in 2006, a resource manager from the Ontario Ministry of Natural Resources used the report to establish priorities for HAB research and response.

A globally expanding problem in marine and freshwater environments (Glibert and Burkholder 2006), HABs are proliferations of microscopic algae that produce toxins that may accumulate in fish and shellfish (HARRNESS 2005; Figure 4). HABs can influence ecosystem structure and function through mechanisms such as food-web alteration (Turner and Tester 1997); light attenuation (Etheridge and Roesler 2004); depletion of dissolved oxygen (Anderson et al. 2002); and disease and mortality among fish, sea birds, and marine mammals (Landsberg 2002).

HABs also have profound socioeconomic consequences, primarily because human recreation, habitation, and commerce are often located in harm's way. Consumption of contaminated shellfish or fish, or exposure to aerosolized toxins produced by a HAB species (Karenia brevis) found in the Gulf of Mexico, can cause human illness or death (Backer et al. 2003). Closure of beaches and fisheries to protect public health can result in loss of recreational and commercial opportunities, reduction of food supply, disruption of subsistence activities, loss of community identity tied to coastal resource use, and stress in affected families and communities (Panel 1). Economic costs associated with public health, fisheries, recreation, and tourism impacts, as well as diversion of funds for monitoring and management, can be substantial for local communities (Hoagland et al. 2002) and, as a result of market linkages, for locations at considerable distances from the source of the outbreak (Wessels et al. 1995). Psychological research has also revealed that the greatest threats of economic harm can be tied to perceptions that shellfish and other seafood products are contaminated, irrespective of actual contamination, a phenomenon known as risk amplification (Kasperson and Kasperson 1996).
We describe three human dimensions research needs for HABs, one each under the umbrellas of human causes, consequences, and responses. Although not exhaustive, these examples illustrate the value of human dimensions research for coastal decision making in general.

\section{Human causes}

Humans have transformed the land and sea, altered major biogeochemical cycles, and added and removed species from ecosystems (Lubchenco 1998). Human activities (anthropogenic drivers) are causes of environmental degradation that lead to consequences in the form of changes in the structure or function of ecosystems, ultimately influencing human health and society. Human causes include population growth and migration to the coast, development and armoring of the coast, release of nutrients to coastal waters, overexploitation of fisheries, and destruction of wetlands.

\section{Example research priority: socioeconomic drivers of human behavior}

A complex and dynamic mix of social, cultural, and economic factors shapes human behavior, which, in turn, can cause ecosystem stress. Understanding these drivers can contribute to the design of strategies to protect, restore, and sustain critical ecosystem services. A lack of understanding, however, can lead to unintended, and ultimately destructive, social and environmental consequences.

There is a clear relationship between the eutrophication of coastal waters and human sources of nutrients, such as sewage, atmospheric deposition, groundwater flow, and agricultural and aquaculture runoff. Under certain conditions, excess nutrients may fuel excessive growth of phytoplankton, which can reduce light penetration, limit seagrass growth, and create low-oxygen conditions (hypoxia) through algal decomposition. Such conditions 


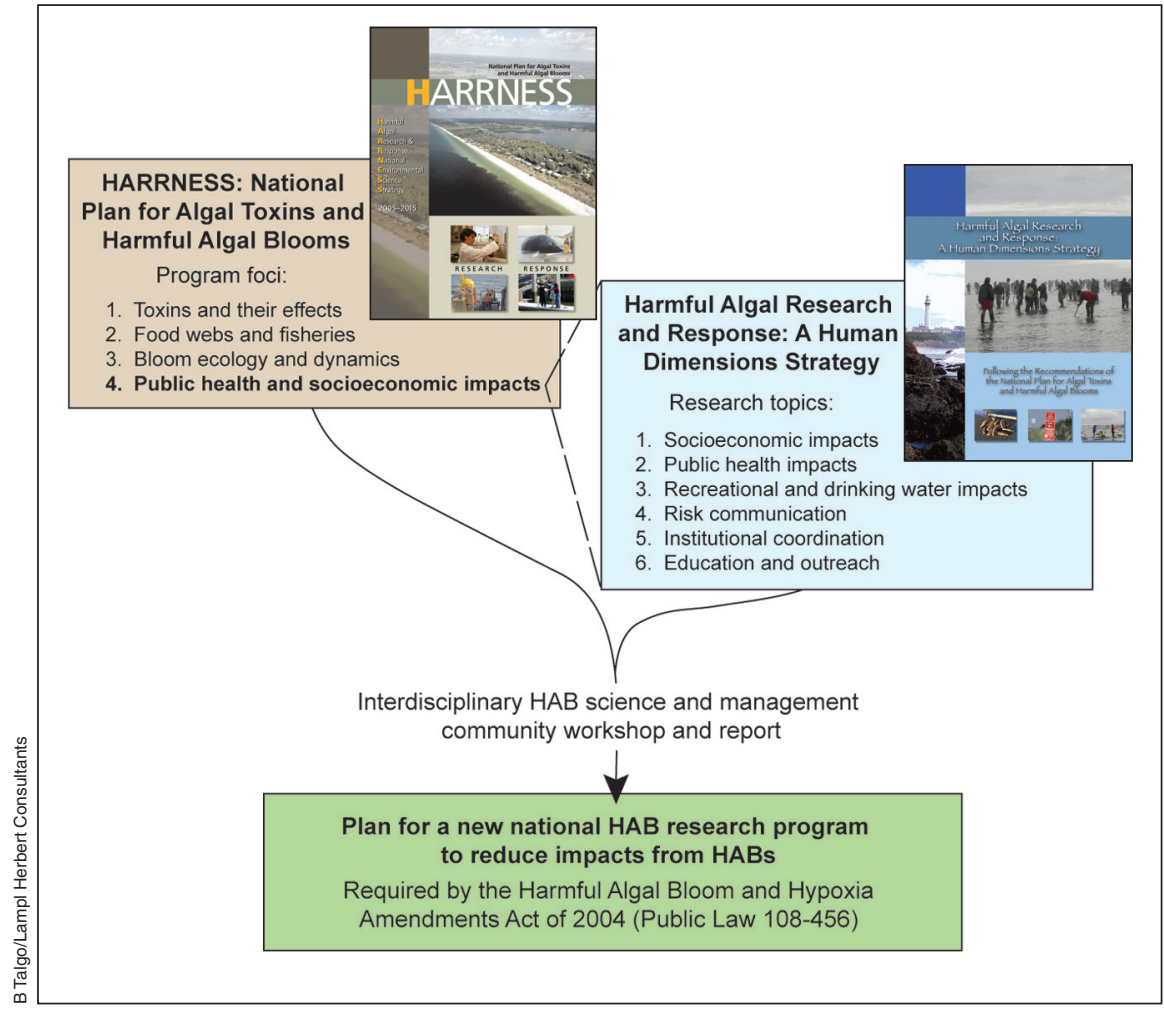

Figure 3. Diagram illustrating research priorities put forth in Harmful algal research and response: a human dimensions strategy, which builds on the National HAB Plan (HARRNESS) and informed a congressionally mandated plan that proposes a new national research program to reduce impacts of HABs.

research is necessary to fully understand the link between nutrients and $\mathrm{HABs}$, a national imperative to reduce nutrient pollution is well established (Bricker et al. 2007).

Reducing the adverse consequences of HABs that are worsened by nutrient loads requires identifying and changing the underlying causes of the loads. Numerous human activities cause nutrient loads, including wastewater disposal, agricultural runoff, fertilization of lawns and golf courses, and atmospheric deposition of nitrogen due to emissions from automobiles and

threaten the abundance and diversity of recreationally, culturally, and commercially important biological resources. Moreover, in some cases, nutrient loadings may confer a competitive advantage to HABs vis-à-vis other algal species (Anderson et al. 2002). Although further power plants. These activities occur at different scales and in different proportions, depending upon geographic location, environmental conditions, and human demographics. Thus, in order to tailor appropriate responses to mitigate the consequences, it is important to characterize human activities that cause nutrient loads and to under-

\section{Panel 1. Social and economic value of razor clams}

The subsistence and cultural values of razor clams (Siliqua patula) underscore the importance of toxicity detection systems developed through a novel partnership between management agencies, coastal Indian tribes, businesses, public interest groups, and academic institutions. Razor clams are such an important resource for Pacific Northwest tribes that the Quinault language has a phrase for "clam hungry" - ta'a Wshi xa' iits 'os. More clams are consumed by tribal members for subsistence than by any other West Coast group. Nearly $20 \%$

Table 1. Economic value of annual razor clam harvest to the Quinault tribe of coastal Washington State, 2003-2006

\begin{tabular}{lcccc}
\hline Year & 2003 & 2004 & 2005 & 2006 \\
\hline $\begin{array}{l}\text { Clams harvested (millions) } \\
\begin{array}{l}\text { Estimated pounds of clams } \\
\text { (in the shell) }\end{array}\end{array}$ & 2.05 & 1.4 & 2.17 & 2 \\
Estimated value & 512500 & 350000 & 542500 & 500000 \\
\hline & $\$ 641000$ & $\$ 438000$ & $\$ 678000$ & $\$ 400000$
\end{tabular}

of the annual harvest goes to subsistence, whereas $80 \%$ is a source of earnings for tribal members (Table I).

Clams are tested for toxicity by tribal members using a new, enzyme-linked, immunosorbent assay (ELISA), developed at the request of the Quinault Tribe in Taholah,WA. Lost clam harvest revenues due to domoic acid (DA) toxicity have been estimated at more than $\$ 640000$ in 2003 for this tribe alone. Tribes are developing the ability to test their clam harvests for DA levels within I.5 to 2 hours of sampling, at a cost of approximately $\$ 10$ per sample. Previously, testing took a minimum of 2 days and cost $\$ 115$ per sample. This ability, combined with monitoring efforts and networking with HAB researchers, has provided new management options for Pacific Northwest tribes.

These and other improvements in early detection systems were accomplished with the assistance of NOAA and other researchers who worked in collaboration with local partners and state regulators through an innovative enterprise known as the Olympic Region Harmful Algal Blooms (ORHAB; www.orhab.org/index.html) Partnership. The highly collaborative nature of ORHAB led to a research agenda strongly focused on practical needs, but undertaken in a way that also led to improved understanding of the biophysical mechanisms by which DA is produced and concentrated in shellfish along the Pacific Northwest coast. Managers gained much needed flexibility in decisions about health-based fisheries closures, thereby lowering the social and economic costs of safety regulation to the benefit of the regional economy. Institutional studies, an important component of human dimensions research, are improving our understanding of why the ORHAB Partnership has been so successful. This information may assist in replicating the ORHAB model of collaboration in other regions prone to HAB outbreaks (Leschine and Chadsey 2007). 
stand and modify the reasons behind the behaviors that lead to these activities. Toward this end, Segerson and Walker (2002) review economic factors encouraging the use of fertilizers - such as government programs supporting fertilizerintensive crops - and apply this understanding to evaluate alternative pollution abatement approaches. Where incentives exist for participation, such as lowered costs of repeated fertilizer applications, the authors identify voluntary approaches as potentially effective means for pollution reduction.

Voluntary approaches have been successfully implemented to control nitrogen runoff from agricultural land in Maryland's Pocomoke River watershed. In 1997, however, a large-scale fish kill resulted from a bloom of the dinoflagellate Pfiesteria piscicida. The apparent cause of the bloom was bioavailable phosphorus, originating from local agricultural operations that use poultry

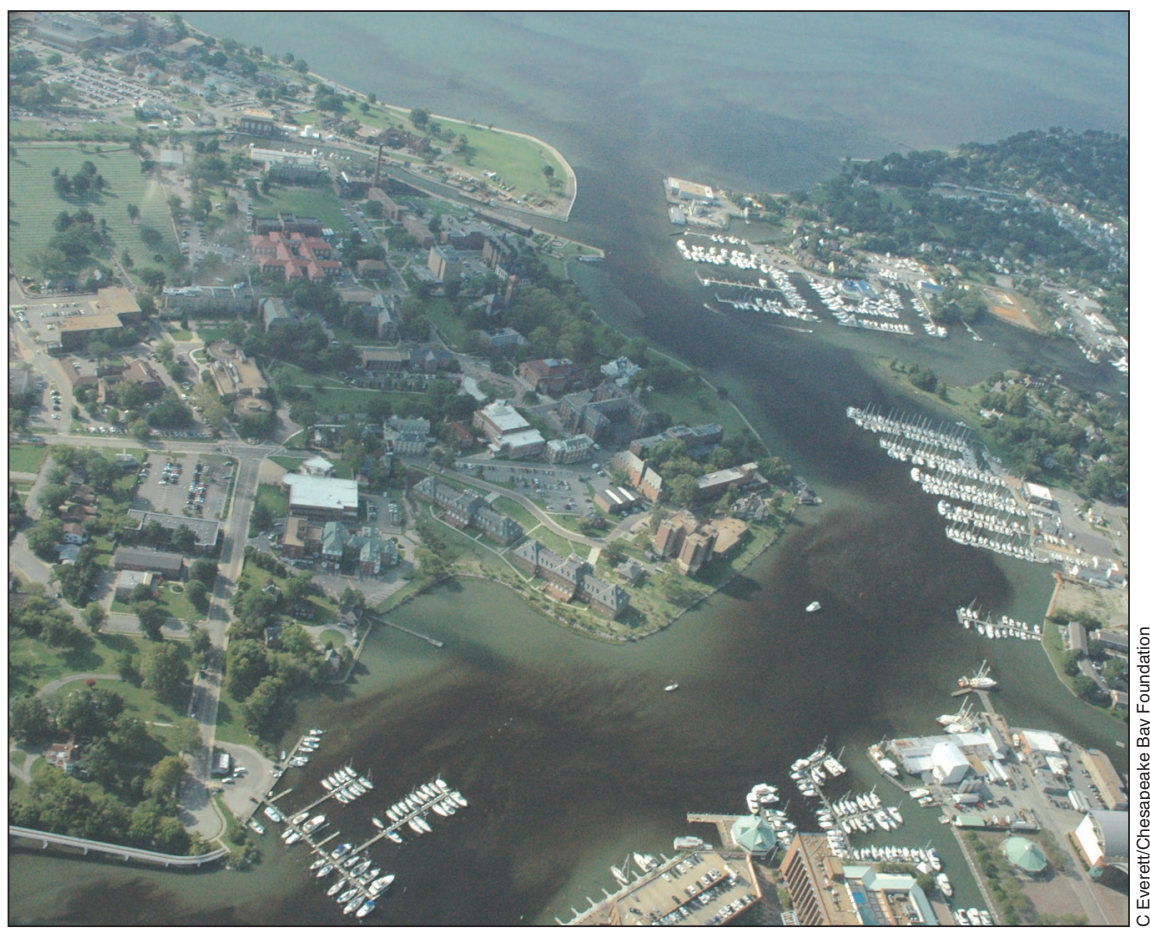

litter for fertilizer. Human dimensions research (in this case, an anthropological study) concluded that the environmental ethic of local farmers was almost identical to that of environmental professionals (Paolisso and Maloney 2000). This prevalence of "farmer environmentalism" suggested that, with appropriate scientific guidance on controlling phosphorus runoff, local farmers could continue the voluntary approach to pollution control. In this case, however, as a result of the immediacy of public health threats from $P$ piscicida, political discourse instead cast the farmers as "polluters", and legislators enacted mandatory pollution control regulations. Although the human dimensions research occurred too late to inform the policy-making process in this case, research of this type may be beneficial in identifying strategies to promote environmentally responsible behavior in similar situations elsewhere.

\section{Consequences to humans}

Changes in ecosystem services impact every dimension of human and social welfare, including public health, personal property and social infrastructure, social relations, culture, and economic welfare. The scale and extent of the consequences of environmental disruption depend on the vulnerability, resilience, and subsequent responses of human communities. As applied to social systems, resilience can be defined as "the ability of groups or communities to cope with external stresses and disturbances as a result of social, political, and environmental change" (Adger 2000). As applied to linked social-ecological systems, resilience can be redefined as the capacity "to absorb recurrent disturbances such as hurricanes or floods, so as to retain essential structures, processes, and feedbacks". In this context, resilience reflects a system's capacity to learn and adapt to change (Adger et al. 2005). Conversely, vulnerability is an erosion of resilience that weakens "[the] capacity to anticipate, cope with, resist, and recover" from impacts (Wisner et al. 2004). A focus on resilience and vulnerability highlights the role of institutions in environmental management (Adger 2000) and emphasizes cross-scale linkages and feedbacks that receive little attention when natural science alone is used to inform policy and management.

\section{Example research priority: minimizing undesirable consequences by increasing community resilience}

Resilience, a key feature of sustainable communities, is influenced by a suite of socio-cultural, political, and environmental factors. Understanding these factors can enable the development of effective strategies for adapting to change. Failure to understand the nature and sources of community resilience and vulnerability can lead to strategies that undermine - rather than enhance - sustainability in social and ecological terms.

Since 1973, over 150 outbreaks of paralytic shellfish poisoning (PSP) have been reported in Alaska, with three fatalities since 1994 (Gofman et al. 2008). These outbreaks have adverse public-health consequences caused by a combination of naturally occurring HABs and a human activity, that is, the harvesting and consumption of shellfish from affected locations. Traditionally, to avoid PSP, indigenous Aleut communities relied on local knowledge about indicators of shellfish safety, such as season and location of collection (Harmon and Khanna 
2008). However, warming in the Arctic has changed environmental conditions, making traditional knowledge less reliable and increasing the risk of shellfish poisoning.

Ongoing research by Gofman et al. (2008) suggests that documenting changes in, and uses of, traditional knowledge, and augmenting traditional knowledge with data obtained through community-based surveillance, will enable Aleut communities to reduce the risk of PSP. Although the outcome has yet to be determined, human dimensions research - in the form of a survey documenting Aleut beliefs and practices related to shellfish collection and consumption - provides the basis for evaluating the reliability of traditional knowledge (Harmon and Khanna 2008). The survey not only describes an important source of cultural meaning for Aleut communities, but also helps identify monitoring needs. Researchers hypothesize that monitoring the occurrence and distribution of PSP toxins will increase the capacity of Aleut communities to reduce risk in cases where traditional knowledge is rendered unreliable by warmer conditions.

\section{- Human responses}

If acting rationally, humans strive to protect, restore, and sustain what they value by mitigating deleterious environmental change and adapting to its undesirable consequences. For example, there is a wide array of societal responses to HABs. Resource management actions include environmental monitoring, public advisories, and fisheries closures. Public-health responses include seafood safety testing, diagnosis and treatment of HAB-related illnesses, and surveillance of exposure and disease. Community strategies include creating alternative recreational opportunities to maintain tourism and thereby support local businesses during a bloom; developing public or private programs to provide social assistance and economic relief to temporarily unemployed fishermen; and developing educational programs to help ethnically diverse populations avoid exposure. From a preventative standpoint, in areas where HABs have been linked to anthropogenic sources of nutrients, voluntary or mandatory nutrient management strategies may be important.

Human dimensions research needs - to support mitigation and adaptation - are diverse. Research is necessary to guide risk communication (McComas 2006), resolve stakeholder conflict (Lewicki et al. 2003), develop incentives for environmentally responsible behavior (Hanna 1998), address ethical concerns (Blount 2003), assess the economic costs and benefits of alternative actions (Hoagland and Scatasta 2006), design effective institutional mechanisms (Ostrom 1990), build community capacity (Garcia-Quijano 2006), and improve coastal decision-making processes that combine scientific analysis and stakeholder deliberation (NRC 1992). Risk communication research and support for institutional development are particularly critical to $\mathrm{HAB}$ responses.

\section{Example research priority: risk communication and support for institutions}

Communication plans that include pre-tested messages and delivery strategies, as well as protocols for institutional coordination, can reduce human and societal impacts of HABs by facilitating public trust, understanding, and protective behavior. The absence of such plans leaves individuals and communities vulnerable and reduces the likelihood of effective responses and outcomes.

A nascent US HAB science program is generating the understanding and tools needed to detect, analyze, and predict HABs (Anderson and Ramsdell 2005). Applying these scientific capabilities to manage the nation's coastal waters is mainly a communication challenge. As the National Science and Technology Council explains in Grand challenges for disaster reduction (2005), to be effective in protecting human well-being, scientific information must be communicated in such a way that people understand the risks, trust the messages, and respond in ways that protect public-health. Building trust is critical, and requires a process of public engagement in which resource managers, public-health officials, and other communicators demonstrate knowledge and expertise, openness and honesty, and concern and care (Peters et al. 1997).

For example, when toxins reach critical levels, publichealth officials and managers of a popular recreational razor clam fishery in Washington State must rapidly communicate closure information, seafood safety guidelines, and medical response instructions to as many as 30000 clam diggers per day; to subsistence and other consumers of potentially contaminated razor clams; to mass media; and to hundreds of coastal business owners whose purchasing, staffing, and other decisions depend on expected tourist influx. These audiences are characterized by diverse perceptions of risks, knowledge of $\mathrm{HABs}$, resource uses, levels of trust in resource management and public-health officials, cultural attributes, and information sources.

Developing formal communication plans for $\mathrm{HAB}$ responses requires human dimensions research in two areas. First, risk communication research is needed to design effective communication messages and strategies. Providing information about risk factors does not necessarily influence an audience's feelings or behavior (Lipkus et al. 1999). Instead, lay audiences' judgments of the severity and acceptability of risks are influenced by factors such as familiarity, controllability, scientific understanding, and feelings (Slovic 1987; Slovic et al. 2004). Risk communication specialists use social science methods such as focus groups, message pre-test studies, and field surveys to evaluate the effectiveness of alternative messages and delivery mechanisms for promoting trust and risk-reducing behavior. A "mental models approach" to message design uses interviews to identify gaps between technical and lay understanding of risks (McComas 2006). Gaps suggest information that, if included in communication messages, 
will help audiences understand risks and adjust their behaviors to prevent harm.

Second, research is needed to build institutional capacity for effective risk communication. Delivering scientifically accurate, complete, timely, and understandable messages requires coordination among many parties, including scientists; resource managers; public-health officials; hotel and other business owners; lifeguards; mass media; subsistence, commercial, and recreational harvesters; local residents; and visitors. Research is needed to analyze and improve formal and informal approaches to communication within this complex network.

Effective communication is a priority, not only in responding to HABs but also in evaluating and possibly implementing innovative methods for controlling algal blooms. Control measures encompass mechanical, biological, chemical, genetic, and environmental strategies that kill $\mathrm{HAB}$ organisms, limit their growth and proliferation, and remove them from the water column. Despite studies suggesting that clay dispersal is a promising method for controlling HABs (Sengco and Anderson 2004; Figure 5), public attitudes toward this approach range from reasonably doubtful to strongly negative. At a 2006 public forum (on HAB research conducted in the Gulf of Mexico), coastal residents voiced concern that clay dispersal (1) introduces an "unnatural" substance into coastal waters and (2) may have unforeseen environmental and public-health impacts that are worse than the blooms themselves.

As these public concerns illustrate, societal reactions may influence whether and how research on HAB control moves beyond an experimental scale to field demonstration and implementation. Societal decisions weighing the risks and expected benefits of alternative control options will influence the level of fiscal investment and design of permitting processes for clay dispersal, and public outcry could directly impede field demonstration and implementation. Public trust, understanding, and informed participation in decision making are essential to ensure the responsible development and effective implementation of $\mathrm{HAB}$ control. Strategies and institutions for effective risk communication are critical toward this end.

\section{- Promoting institutional change}

Integrating human dimensions research and researchers into the science and practice of US and international coastal resource management will require substantial institutional changes to our nation's coastal science and education programs. The US Department of Commerce recently released a Human Dimensions Strategic Plan, which aims to foster improved support of coastal decision making by expanding their science program to include an integral focus on human dimensions (NOAA/NCCOS 2007). Strategic human dimensions research objectives encompass topics such as socioeconomic drivers of ecosystem stress, societal consequences of management, participatory decision making, traditional and local ecological knowledge, institutions, ethics, integrated ecosystem assessment and modeling, risk and vulnerability, and risk communication. The plan also makes a commitment to provide institutional support for such research, recognizing that needs include human dimensions research staff, a human dimensions literate workforce, integrated environmental and human dimensions research prioritization and planning, adequate funding for human dimensions research, new interdisciplinary partnerships, and leadership with interdisciplinary team-building skills.

To support coastal management, science and education programs must recognize that "we are not students of some subject matter, but students of problems. And problems may cut right across the borders of any subject matter or discipline" (Popper 1963). As illustrated by the HAB examples discussed here, coastal problems require supporting science and solutions focused not on any isolated human or environmental component of an ecosystem, but on interactions between them. Strategic guidance documents provide a foundation for the development of institutional capacities to integrate human dimensions research and researchers into coastal science, education and decision making, to enhance societal outcomes. Without those capacities, the contributions of human dimensions research toward solving problems in coastal waters are less likely to be a part of best management strategies. 


\section{Acknowledgements}

This paper was developed with partial support from NOAA's National Centers for Coastal and Ocean Science. The authors thank $G$ Matlock for comments on a draft. Thomas Leschine's contributions to this publication were supported by grant number P50 ES012762 from the National Institute of Environmental Health Sciences (NIEHS), NIH, and OCE-0434087 from the National Science Foundation. Its contents are solely the responsibility of the authors and do not necessarily represent the official views of the NIEHS, NIH, or NSF.

\section{References}

Adger WN. 2000. Social and ecological resilience: are they related? Prog Hum Geog 24: 347-64.

Adger WN, Hughes TP, Folke C, et al. 2005. Social-ecological resilience to coastal disasters. Science 309: 1036-39.

Anderson DM, Glibert PM, and Burkholder JM. 2002. Harmful algal blooms and eutrophication: nutrient sources, composition, and consequences. Estuaries 25: 704-26.

Anderson DM and Ramsdell JS. 2005. HARRNESS - a framework for $\mathrm{HAB}$ research and monitoring in the United States for the next decade. Oceanography 18: 238-45.

Backer LC, Fleming LE, Rowan AD, and Baden DG. 2003. Epidemiology and public health of human illnesses associated with harmful marine algae. In: Hallegraeff GM, Anderson DM, and Cembella AD (Eds). Manual on harmful marine microalgae. Paris, France: UNSECO Publishing.

Bauer M (Ed). 2006. Harmful algal research and response: a human dimensions strategy. Woods Hole, MA: National Office for Marine Biotoxins and Harmful Algal Blooms, Woods Hole Oceanographic Institution. http://coastalscience.noaa.gov/ stressors/extremeevents/hab/HDstrategy.pdf. Viewed 22 Apr 2008.

Blount BG. 2003. Perceptions of legitimacy in conflict between commercial fishermen and regulatory agencies: some ethical concerns. In: Dallmeyer D (Ed). Values at sea: ethics for the marine environment. Athens, GA: University of Georgia Press.

Bricker S, Longstaff B, Dennison W, et al. 2007. Effects of nutrient enrichment in the nation's estuaries: a decade of change. Silver Spring, MD: National Centers for Coastal Ocean Science. NOAA Coastal Ocean Program Decision Analysis Series No 26.

Butler CD and Oluoch-Kosura W. 2006. Linking future ecosystem services and future human well-being. Ecol Soc 11: 30.

Collins SL, Swinton SM, Anderson CW, et al. 2007. Integrative science for society and environment: a strategic research plan. Research Initiatives Subcommittee of the Long Term Ecological Research Planning Process Conference Committee and the Cyberinfrastructure Core Team. http://intranet.lternet.edu/modules.php?name $=\mathrm{UpDownload} \&$ req $=$ getit $\&$ lid $=55$ 9. Viewed 9 Dec 2008.

Dortch Q, Anderson DA, Ayers D, et al. 2008. Harmful algal bloom research, development, demonstration, and technology transfer: a national workshop report. Woods Hole, MA: National Office for Harmful Algal Blooms, Woods Hole Oceanographic Institution. www. whoi.edu/fileserver.do?id $=43464 \& p t=10 \& p=$ 19132. Viewed 10 Oct 2008

Endter-Wada J, Blahna D, Krannich R, and Brunson M. 1998. A framework for understanding social science contributions to ecosystem management. Ecol Appl 8: 891-904.

Etheridge SM and Roesler CS. 2004. Temporal variations in phytoplankton, particulates, and colored dissolved organic material based on optical properties during a Long Island brown tide compared to an adjacent embayment. Harmful Algae 3: $331-42$

Garcia-Quijano C. 2006. Resisting extinction: the value of local ecological knowledge for small-scale fishers in southeastern Puerto Rico (PhD dissertation). Athens, GA: University of Georgia.

Glibert PM and Burkholder JM. 2006. The complex relationships between increases in fertilization of the earth, coastal eutrophication, and proliferation of harmful algal blooms. In: Graneli E and Turner JT (Eds). Ecology of harmful algae. New York, NY: Springer.

Gofman V, Wright B, and RaLonde R. 2008. Response and intervention system for climate change induced paralytic shellfish poisoning in Aleut communities. Anchorage, AK: North Pacific Re-search Board.http://project.nprb.org/view.jsp?id=c 974307d-3e90-4f56-adb3-d6c370d38dd0. Viewed 22 Apr 2008.

Hanna SH. 1998. Institutions for marine ecosystems: economic incentives and fishery management. Ecol Appl 8: S170-74.

Harmful Algal Bloom and Hypoxia Amendments Act of 2004. 16 USC $\S \S 1451$ note.

Harmon M and Khanna K. 2008. Survey of local and traditional knowledge about paralytic shellfish poisoning in Alaskan and Russian Aleut communities. Anchorage, AK: Aleut International Association. www.aleut-international.org/files/Down load/Final\%20AIA\%20Report\%20WESTAT-\%20PSP\%20 Survey\%205-28-08.pdf. Viewed 22 Apr 2008.

HARRNESS. 2005. Harmful algal research and response: a national environmental science strategy 2005-2015. Washington, DC: Ecological Society of America. www.esa. org/HARRNESS/harrnessReport10032005.pdf. Viewed 22 Apr 2008.

Harwell MA, Long JF, Bartuska AM, et al. 1999. Ecosystem management to achieve ecological sustainability: the case of South Florida. Environ Manage 20: 497-521.

Hoagland P and Scatasta S. 2006. The economic effects of harmful algal blooms. In: Granéli E and Turner JT (Eds). Ecology of harmful algae. Berlin, Germany: Springer-Verlag.

Hoagland P, Anderson DM, Kaoru Y, and White AW. 2002. The economic effects of harmful algal blooms in the United States: estimates, assessment issues, and information needs. Estuaries 25: 819-37.

Jewett EB, Lopez CB, Dortch Q, et al. 2008. Harmful algal bloom management and response: assessment and plan. Washington, DC: Interagency Working Group on Harmful Algal Blooms, Hypoxia, and Human Health of the Joint Subcommittee on Ocean Science and Technology. http://ocean.ceq.gov/about/ docs/jsost hab0908.pdf. Viewed 10 Oct 2008.

Kasperson RE and Kasperson JX. 1996. The social amplification and attenuation of risk. Ann Am Acad Polit SS 545: 95-105.

Landsberg JH. 2002. The effects of harmful algal blooms on aquatic organisms. Rev Fish Sci 10: 1-113.

Leschine TM and Chadsey M. 2007. Science and management for harmful algal blooms. Proceedings of Coastal Zone 07; 22-26 Jul 2007; Portland, OR. Silver Spring, MD: NOAA. www.csc.noaa.gov/cz/2007/Coastal_Zone_07_Proceedings/PDFs /Thursday_Abstracts/3450.Leschine.pdf. Viewed 22 Apr 2008.

Lewicki RJ, Gray B, and Elliott M. 2003. Making sense of intractable environmental conflicts: frames and cases. Washington, DC: Island Press.

Lipkus IM, Crawford Y, Fenn K, et al. 1999. Testing different formats for communicating colorectal cancer risk. J Health Commun 4: 311-24.

Lubchenco J. 1998. Entering the century of the environment: a new social contract for science. Science 279: 491-97.

MA (Millennium Ecosystem Assessment). 2005. Ecosystems and human well-being: synthesis. Washington, DC: Island Press. www.millenniumassessment.org/documents/document.356.asp x.pdf. Viewed 22 Apr 2008.

McComas KA. 2006. Defining moments in risk communication research: 1996-2005. J Health Commun 11: 75-91.

National Science and Technology Council. 2005. Grand challenges for disaster reduction. Washington, DC: Committee on 
Environment and Natural Resources, Subcommittee on Disaster Reduction. www.sdr.gov/SDRGrandChallengesfor DisasterReduction.pdf. Viewed 22 Apr 2008.

NOAA (National Oceanic and Atmospheric Administration)/NCCOS (National Centers for Coastal Ocean Science). 2007. Human dimensions strategic plan (FY2009-FY2014). Washington, DC: National Centers for Coastal Ocean Science. http://coastalscience.noaa.gov/human/ strategy/NCCOSHDPlan.pdf. Viewed 22 Apr 2008.

NOAA (National Oceanic and Atmospheric Administration)/SSRP (Social Science Review Panel). 2003. Social science research within NOAA: review and recommendations. Washington, DC: NOAA Scientific Advisory Board. www.economics.noaa.gov/library/documents/social_science_in itiative/social_science_research_within_noaa-review_recommend.doc. Viewed 22 Apr 2008

NRC (National Research Council). 1992. Global environmental change: understanding the human dimensions. Washington, DC: National Academies Press.

NRC (National Research Council). 2008. Participation in environmental assessment and decision making. Washington, DC: National Academies Press.

Ostrom E. 1990. Governing the commons: the evolution of institutions for collective action. Cambridge, UK: Cambridge University Press.

Paolisso M and Maloney RS. 2000. Recognizing farmer environmentalism: nutrient runoff and toxic dinoflagellate blooms in the Chesapeake Bay region. Hum Organ 59: 209-21.

Peters RG, Covello VT, and McCallum DB. 1997. The determinants of trust and credibility in environmental risk communication: an empirical study. Risk Anal 17: 43-54.

Popper KR. 1963. Conjectures and refutations: the growth of scientific knowledge. New York, NY: Routledge.

Reiter MA, Parsons GR, Scarborough RW, et al. 2006. An interdisciplinary conceptual metamodel for the St Jones River Watershed, Delaware: development, results, and implications. J Environ Monit Restor 2: 38-50.

Segerson K and Walker D. 2002. Nutrient pollution: an economic perspective. Estuaries 25: 797-808.

Sengco MR and Anderson DM. 2004. Controlling harmful algal blooms through clay flocculation. J Eukaryot Microbiol 51: 169-72.

Slovic P. 1987. Perception of risk. Science 236: 280-85.

Slovic P, Finucane ML, Peters E, and MacGregor GM. 2004. Risk as analysis and risk as feelings: some thoughts about affect, reason, risk, and rationality. Risk Anal 24: 311-22.

Turner JT and Tester PA. 1997. Toxic marine phytoplankton, zooplankton grazers, and pelagic food webs. Limnol Oceanogr 42: 1203-14.

US Commission on Ocean Policy. 2004. An ocean blueprint for the 21st century. Washington, DC: US Commission on Ocean Policy. www.oceancommission.gov/documents/full_color_rpt/ 000_ocean_full_report.pdf. Viewed 22 Apr 2008.

Weiher RF. 2006. NOAA social science: implementing recommendations of the Science Advisory Board: status and next steps. A briefing to the NOAA Science Advisory Board, March 9. Silver Spring, MD: NOAA. www.economics.noaa.gov/library/ documents/social_science_initiative/SocialScienceProgress Brief-SAB.ppt. Viewed 22 Apr 2008.

Wessels CR, Miller CJ, and Brooks PM. 1995. Toxic algae contamination and demand for shellfish: a case study of demand for mussels in Montreal. Mar Res Econ 10: 143-59.

Wisner B, Blaikie P, Cannon T, and Davis I. 2004. At risk: natural hazards, people's vulnerability and disasters, 2nd edn. New York, NY: Routledge.

${ }^{2}$ Marine Policy Center, Woods Hole Oceanographic Institution, Woods Hole, MA; ${ }^{3}$ School of Marine Affairs, University of Washington, Seattle, WA; ${ }^{4}$ SocioEcological Informatics, Helotes, TX; ${ }^{5}$ California Sea Grant Extension Program, Watsonville, CA; ${ }^{6}$ Lampl Herbert Consultants Inc, Tallahassee, FL; ${ }^{7}$ Cornell University, Ithaca, NY; ${ }^{8}$ Washington State Department of Fish and Wildlife, Region Six Office, Montesano, WA; ${ }^{9} \mathrm{NOAA}, \mathrm{NOS}$, NCCOS, Center for Coastal Fisheries and Habitat Research, Beaufort, NC; ${ }^{10}$ Smithsonian Environmental Research Center, Edgewater, MD; ${ }^{11}$ Chesapeake Research Consortium, Edgewater, MD; ${ }^{12}$ Quinault Department of Natural Resources, Taholah, WA

\section{Don't forget!}

\section{Renew your ESA Membership for 2010}

\section{Some benefits of membership include:}

Networking opportunities with 10000 professional ecologists and students worldwide

A subscription to Frontiers in Ecology and the Environment

- Substantial savings on ESA Annual Meeting registration and Professional Certification fees

Member-only subscriptions to Ecology, Ecological Applications, and Ecological Monographs

For fastest processing, renew online at http://eservices.esa.org or download a PDF form from www.esa.org/member_services/join_renew.php

If you have any questions regarding your 2010 renewal, please contact Lilly Schwartz at membership@esa.org or by phone at 202-833-8773 ext. 216. 